\title{
CORPORATE FINANCIAL PERFORMANCE, CORPORATE ENVIRONMENTAL PERFORMANCE, CORPORATE SOCIAL PERFORMANCE AND STOCK RETURN
}

\author{
Nera Marinda Machdar \\ Faculty of Economics, Department of Accounting, Kalbis Institute, Jakarta, Indonesia \\ Email: nera.marinda@kalbis.ac.id
}

\begin{abstract}
The purpose of this study is to examine the influence of corporate financial performance, corporate environmental performance and corporate social performance on the stock return. The study used 22 companies/ firms' financial statements for the period 2009 to 2015. The results show that: (a) corporate financial performance influences positively stock return. It means that investors pay more attention to marketbased measures over accounting-based measures; (b) corporate environmental performance influences negatively stock return. This indicates that investors do not consider the relative environmental choices of the companies or that stock market does not like hearing about the environmental news, and (c) corporate social performance does not influence stock return. This is probably because investors are not interested in the social news. There are other data that can be obtained as a consideration in the decision making.
\end{abstract}

Keywords: Financial performance, environmental performance, social performance, stock returns.

\section{Introduction}

Share investments have become one of the various investment options that are quite attractive to foreign and local investors. The motive which drives an investor or a business entity to invest funds in shares is the expectation of the high rate of return or the acquisition a company (Anwaar, 2016). Financial reporting is one alternative that is used by investors to evaluate the past, current and future potential performance and financial position of the companies.The role of financial reporting is to provide information about the fiscal health and financial performance of the firms. Performance measurement is critical for effective management of any firm (Demirbag, Tatoglu, Tekinus, \& Zaim, 2006). The firm's success is basically explained by its performance over a certain period of time. Corporate performance is a key concept in today's economic environment, shaped by rapid changes, fierce competition, and globalization (Vintila \& Nenu, 2015).

In recent years, the stakeholders of companies such as shareholders, employees, investors, governments, local communities, trading partners, consumers, and non-governmental organizations are conscious of their interests on corporate management (Pan, Sha, Zhang, \& Ke, 2014). In a world of limited resources and increased requests for social welfare, businesses should be concerned with issues such as environmental damage, product safety and human resource management (Leite, Padgett, \& Galán, 2014). In response to this concern, companies face increasing pressure to maximize social performance and financial performance. Growing public awareness of environmental and social issues has led to a heightened demand for financial mechanisms that enhance responsible business practice (Lagas, 2013).

Corporate environmental reputation contains value-relevant information which is potentially useful to investors in anticipating future earnings (Hussainey $\&$ Salama, 2010). Therefore, accountants should give high priority to develop appropriate and complete environmental disclosure practices in order to achieve an effective financial communication with investors. Cormierand Magnan (2007) supported that the environmental reporting will be likely used by investors to better assess firm's earnings prospects and reduce implied uncertainty.

Vintila and Nenu (2015) grouped financial ratios into four categories, such as liquidity, solvency, profitability and asset utilization. In regarding with performance it can be concluded to three significant categories, such as profitability, management performance, and liquidity. Theoretical empirical studies on the relationship between corporate financial performance (hereafter CFP) and corporate social performance (hereafter CSP) have done by some researchers providing mixed results. Early studies argued that CSP reacts positively to CFP (Waddock \& Graves, 1997; Margolis \&Walsh, 2003; Orlitzky, Schmidt, \& Rynes, 2003; Cormier \& Magnan, 2007; Pan, Sha, Zhang, \& Ke, 2014). Meanwhile, Garcia-Castro, Arino, and Canela (2010) proposed a negatively effect CSP on CFP. Stekelenburg, Georgakopoulos, 
Sotiropoulou, Vasileiou, and Vlachos (2015) explained the relationship between CFP and CSP by using the resource view of stakeholder theory. According to this theory, firms that invest in CSP have superior resources. The resource view proposes that only firms with sufficient resources have the capacity to invest in CSP, and suggests that CSP is positively associated with financial performance because the firms that invest in CSP have greater underlying resources which produce a higher financial performance.

The relationship between corporate environmental performance (CEP) and corporate financial performance (CFP) has been explored in a large number of studies, although there is still providing mixed results about this relationship. Early studies argued that good environmental performance enforces extra costs on firms (Walley \& Whitehead, 1994; Palmer, Oates, \& Portney, 1995); while more recent researches provide evidences to support a positive relationship between CEP and CFP (Konar \& Cohen, 2001; Guenster, Bauer, Derwall, \& Koedijk, 2011). According to Derwall, Guenster, Bauer, \& Koedijk (2005), CEP increases corporate efficiency; and thus, it creates a competitive advantage. As Aggarwal (2013) argued that CEP has a positive impact such as good relation with stakeholders; enhanced reputation; ability to attract and retain qualified employees, investors, and customers; cost savings; operational efficiencies; innovations; long-term orientation; better access to capital; secured license to operate and increase in competitiveness.

In previous studies, scholars sought to find separately the linkage between CFP, CEP, and CSP. However, to the best of the knowledge, there is no study directly examine the effect of CFP, CEP, and CSP on stock returns. This study tries to fill that gap and add to existing literature by investigating the impact of CFP, CEP, and CSP on stock return. The research questions of this study i.e. (1) Does corporate financial performance influence the stock return? (2) Does corporate environmental performance influence the stock return? (3) Does corporate social performance influence the stock return? This study is important for several reasons. First, this study provides insights into the field of CFP, CEP, and CSP. Second, the empirical results of previous studies that examine the information content of separate linkage between CFP, CEP, and CSP is mixed and inconclusive.

Although the definition of CFP is not debated in the literature, there is disagreement with respect to the best way to measure CFP (Cochran \& Wood, 1984). According to Orlitzky, Schmidt, and Rynes (2003), CFP is basically measured in three forms: market, accounting, and survey measurements. The market approach reflects the degree of satisfaction of the shareholders; accounting approach captures an idea of the internal efficiency of the company and survey measurements provide a subjective estimation of its financial performance. Saleh (2015) analyzed the extent to which determinants like net profit margin, return on assets and return on equity influence stock returns with the focus on Oil and Gas sector in Pakistan. The results showed that NPM, ROA, and ROE have substantial influenced over stock returns.Vintila and Nenu (2015) investigated the potential factors of influence on corporate financial performance. The results showed that corporate financial performance is adversely affected by indebtedness. The findings also showed that the corporate financial performance is positively related to company size, quantified by employees number, but in market-based sizes occurred a negative relation to total assets. It can be can be said that a lot of corporate assets have no guarantee for increased development investments or for higher stability in times of crisis. In other words, it is not a guarantee for further evolution. Anwaar (2016) showed that net profit margin and return on assets have significant positive impact on stock returns, earnings per share have significant negative impact on stock returns. While return on equity and quick ratio show the insignificant impact on stock returns. Therefore, this study proposes Hypothesis 1 as follows:

$H_{l}$ : Corporate financial performance influences the stock return.

According to the neoclassical agency theory, the expected costs of a firm's environmental responsibility are likely to outweigh the resulting profits; and hence, a firm's environmental performance is expected to have a negative impact on its profitability (Friedman, 1970). Weir (2010) found that the stock return reacts negatively to news about the environmental behavior of firms. This could mean that investors do not consider the relative environmental choices of firms or that the stock market does not like hearing about the environmental news. In other words, this potentially means that investors place a negative value on environmentally conscious corporations. The stock markets do not believe that environmentally friendly behavior adds any value to a company and even might place negative pressure on firm value. This would be in line with the economic theory discussed earlier that positive environmental behavior leads to decreased profitability. Moneva \& Cuellar (2009) suggested that financial environmental information provides value-relevant information for about the firm value. On the other hand, non-financial environmental information does not provide value-re- 
levant information. Therefore, this study proposes Hypothesis 2 as follows:

$\mathrm{H}_{2}$ : Corporate environmental performance influences the stock return.

Corporate social performance (CSP) is defined as a business organization's configuration of principles of social responsibility, processes of social responsiveness, and policies, programs, and observable outcomes as they relate to the firm's societal relationships (Wood, 1991). CSP is a multidimensional construct that encompasses a large and varied range of corporate behavior in relation to its inputs, internal approaches or processes, and outputs (Waddock \& Graves, 1997). CSP incorporates the interaction between the principles of social responsebility, the processes of social responsiveness, and the policies and programs designed by corporations to address social issues (Leite, Padgett, \& Galán, 2014). Hussainey and Salama (2010) reported that environmental reporting issues affect the quality of reported earning numbers. Meanwhile, Brammer, Brooks, and Pavelin (2006) examined the relationship between corporate social performance and stock returns and presented that CSP reacts negatively to stock return. In other words, companies with higher social performance scores tend to achieve lower returns. On the other hand, companies with the lowest possible CSP scores of zero considerably outperformed the market. Enhanced corporate social performance may lead to improved stock returns either directly through cost reductions and productivity improvements, or indirectly through an improvement in the firm's overall standing that makes analyses more willing to recommend the stock and investors are more willing to hold it irrespective of the firm's costs and revenues (Brammer, Brooks, \& Pavelin, 2006). Therefore, this study proposes hypothesis 3 as follows:

$H_{3}$ : Corporate social performance influences the stock return.

\section{Research Method}

The research population comprises all firms that are listed their stocks on the Indonesia Stock Exchange over the period of 2009-2015. Samples were selected by using purposive sampling with the following criteria: firms consistently published audited financial statements from 2009-2015; firms presented sustainability report using the Global Reporting Initiative (GRI) index, and firms facilitated in PROPER rating. On the basis of these criteria, the total sample consists of 22 companies. This research used secondary data from Indonesia Stock Exchange and Indonesian Capital Market Directory and data PROPER contained in the report's rating of corporate performance in environmental management, published by the Ministry of Environment.This study adopts software EVIEWS 8.0 (Ghozali \& Ratmono, 2013) to do the estimation. Before the regression analysis model is used, following a series classical assumptions are tested. These are including tests of multicollinearity, heteroscedasticity, and autocorrelation. The research model as follows:

$$
\mathrm{RET}_{\mathrm{it}}=\alpha_{0}+\beta_{1} \mathrm{CFP}_{\mathrm{it}}+\beta_{2} \mathrm{CEP}_{\mathrm{it}}+\beta_{3} \mathrm{CSP}_{\mathrm{it}}+\varepsilon_{\mathrm{it}}
$$

Where: $\mathrm{RET}_{i t}=$ stock return of firm iin year $t \mathrm{CFP}_{i t}=$ corporate finance performance of firm $i$ in year $t$; $\mathrm{CEP}_{\mathrm{i}}=$ corporate environmental performance of firm $i$ in year $t, \mathrm{CSP}_{\mathrm{it}}=$ corporate social performance of firm $i$ in year $t$.

Corporate financial performance is measured by calculating the company's Tobin's $Q$.Tobin's $Q$ is one of the indicators most widely used by researchers to measure the financial performance of companies. This is because, in an efficient capital market, Tobin's $q$ minimizes the main shortcomings of accounting indicators (referring to issues arising from tax laws and accounting conventions) (Smirlock, Gilligan, \& Marshall, 1984). Tobin's $Q$ ratio is defined as the ratio between the market value and the book value of its assets.

Corporate environmental performance is measured by the PROPER rating. Corporate environmental performance is measured by the PROPER rating. The use of color in PROPER ratings presents the form of communicative to the public which is started from the best, gold, green, blue, red, up to the worst, black. Scoring is done by using an interval scale as follows: a. Gold: very very good; score $=5 ; \mathrm{b}$. Green: very good; score $=4$; c. Blue: good; score $=3$; d. Red: bad; score $=2$; and e. Black: very bad; score $=$ 1.

Corporate social performance is measured by the index of Global Reporting Initiatives (GRI). GRI contains 30 items and it is measured by using dummy variables. A value of 1 is given if the items are disclosed in the financial statements and the value 0 if the items are not disclosed in the financial statements.

\section{Result and Discussion}

Table 1 presents a summary of descriptive statistics of independent and dependent variables used in the research. Statistics indicate the average, median, standard deviation, minimum, maximum, skewness, and kurtosis. The positive skewness for financial performance variables shows a right tail of the distribution which means a higher frequency of results below the average. 
Tabel 1

Descriptive Statistics

\begin{tabular}{lccccccc}
\hline & RET & CFP & CSP & DGREEN & DBLUE & DRED & DBLACK \\
\hline Mean & 0.307512 & 2.443431 & 0.318500 & 0.045455 & 0.681818 & 0.155844 & 0.103896 \\
Median & 0.130000 & 1.180932 & 0.200000 & 0.000000 & 1.000000 & 0.000000 & 0.000000 \\
Maximum & 4.170000 & 20.84276 & 1.000000 & 1.000000 & 1.000000 & 1.000000 & 1.000000 \\
Minimum & -0.930000 & 0.403031 & 0.000000 & 0.000000 & 0.000000 & 0.000000 & 0.000000 \\
Std. Dev. & 0.754531 & 3.292169 & 0.272596 & 0.208979 & 0.467290 & 0.363891 & 0.306121 \\
Skewness & 2.212751 & 3.034115 & 1.201705 & 4.364358 & -0.780720 & 1.897704 & 2.596332 \\
Kurtosis & 9.573264 & 13.16335 & 3.489476 & 20.04762 & 1.609524 & 4.601282 & 7.740942 \\
JarqueBera & 402.9209 & 899.0841 & 38.60247 & 2353.709 & 28.05058 & 108.8859 & 317.2419 \\
Probability & 0.000000 & 0.000000 & 0.000000 & 0.000000 & 0.000001 & 0.000000 & 0.000000 \\
Sum & 47.35689 & 376.2884 & 49.04900 & 7.000000 & 105.0000 & 24.00000 & 16.00000 \\
Sum Sq. Dev. & 87.10542 & 1658.272 & 11.36925 & 6.681818 & 33.40909 & 20.25974 & 14.33766 \\
Observations & 154 & 154 & 154 & 154 & 154 & 154 & 154 \\
\hline
\end{tabular}

Source: Own processingusing Eviews

Notes: RET $=$ Stock Return, CFP $=$ Corporate Financial Performance, $\mathrm{CSP}=$ Corporate Social Performance, CEP $=$ Corporate Environmental Performance which is measured by Dgreen, Dblue, Dred, and D black.

Table 2

Regression Results

\begin{tabular}{ccllll}
\hline Variable & Coefficient & Std. Error & $\boldsymbol{t}$-Statistic & Prob. \\
\hline C & 1.882104 & 0.583153 & 3.227459 & 0.0016 & \\
CFP & 0.075327 & 0.027611 & 2.728115 & 0.0073 & $* * *)$ \\
CSP & -0.649311 & 0.430425 & -1.508537 & 0.1339 & \\
DGREEN & -1.329325 & 0.636434 & -2.088709 & 0.0387 & $* *)$ \\
DBLUE & -1.613930 & 0.562784 & -2.867762 & 0.0048 & $* * *)$ \\
DRED & -1.444615 & 0.623948 & -2.315281 & 0.0222 & $* *)$ \\
DBLACK & -1.596560 & 0.674758 & -2.366122 & 0.0195 & $* *)$ \\
\hline \multicolumn{7}{c}{ Effects Specification } & & \\
\hline$R$-squared & Cross-section fixed (dummy variables) & & \\
\hline Adjusted $R$-squared & 0.218294 & Mean dependent var & 0.307512 \\
S.E. of regression & 0.050785 & S.D. dependent var & 2.385404 \\
Sum squared reside & 0.735121 & Akaike info criterion & 2.937577 \\
Log likelihood & 68.09084 & Schwarz criterion & 2.609695 \\
$F$-statistic & -155.6761 & HannanQuinn criter. & 2.332832 \\
Prob $(F$-statistic $)$ & 1.303181 & Durbin-Watson stat & \\
\hline Sour & 0.166271 & &
\end{tabular}

Source: Own processing using Eviews

Notes: $\mathrm{RET}=$ Stock Return, CFP $=$ Corporate Financial Performance, $\mathrm{CSP}=$ Corporate Social Performance, $\mathrm{CEP}=$ Corporate Environmental Performance which is measured by Dgreen, Dblue, Dred, and Dblack.

$P$ value $* * *<1 \%, * *<5 \%, *<10 \%$.

The regression results of research models use statistical tools Eviews 8, assuming a constant slope coefficient, intercept varies between individuals and between periods, are presented in Table 2. Table 2 can figure that CFP has a positive coefficient to stock returns. The coefficient of CFP is 0.075327, significant at $10 \%$ level ( $t$-statistic 2.728115 ; sig. 0.0073). It means that corporate financial performance affects stock returns. Therefore, hypothesis 1 is accepted. The CEP is measured by green, blue, red and black. The coefficient of green is-1.329325, significant at 5\% level ( $t$-statistic -2.088709; sig. 0.0387). The coefficient of blue is -1.613930 , significant at $1 \%$ level $(t$ - statistic -2.867762; sig. 0.0048). The coefficient of red is -1.444615 , significant at $5 \%$ level ( $t$-statistic 2.315281; sig. 0.0022). The coefficient of black is1.596560 , significant at $5 \%$ level ( $t$-statistic 2.366122; sig. 0.0195), all of the measurement of CEP has a negative coefficient and significant. It can be concluded that corporate environmental performance affect stock returns. Therefore, hypothesis 2 is accepted. The coefficient of CSP is -0.649311 (negative), $t$-statistic is -1.508537 and insignificant (sig. 0.1339).It presents that corporate social performance does not affect stock returns. Therefore, hypothesis 3 is rejected. 


\section{Conclusions and Implications}

The main objective of this study is to provide knowledge on the impact of CFP, CEP, and CSP on stock return. The results of using fixed-effects panel data regression analysis are referred to Table 2 . The first hypothesis indicates that CFP has a positive impact on the stock return; this result is supported empirically. It is also in line with the finding of Anwaar (2016), Saleh (2015) and Muhammad \& Scrimgeour (2014). Thus, it indicates that investors pay more attention to market-based measures over accounttingbased measures.

The second hypothesis presents that CEP has a negative impact on stock return. This finding in line with Weir (2010) that the corporate environmental performance affects negatively the stock returns. This could mean that investors do not consider the relative environmental choices of firms or that the stock market does not like hearing about the environmental news. Investors react adversely to the green news. In other words, this potentially means that investors place a negative value on environmentally conscious corporations. The stock markets do not believe that environmentally friendly behavior adds any value to a company, and even might place negative pressure on firm value. According to Hassel, Nyquist and Nilsson (2005), CEP disclosures may be perceived as form of green-washing or window-dressing by investors and other stakeholders, CEP responsibilities involve huge costs and therefore reduce firm's profitability, and investors are more interested in short-term gains but environmental efforts provide returns only in longterm.

The third hypothesis shows that the CSP variable coefficient is negative (-0.146) and insignificant. It indicates that CSP has a negative impact and insignificant on stock return.This is probably due investors are not interested in CSP because there is other data, such as CFP and CEP that can be obtained as a consideration in the decision-making. This results are in line with Brammer, Brooks, and Pavelin (2006) and contrary to the resource view of stakeholder theory.

This study has the implications as follows: first, the result is significant for researchers and practitioners seeking to select measures that can empirically explain the performance of the company. It has also importance for shareholders tracking the performance of companies in order to make profitable investments. Second, this finding suggests that CSR provides investors with value-relevant information. This information enables investors to better forecast the future earnings. Accordingly, this leads to more efficient capital markets.
This study has several limitations, which provides directions for future research. First, this study focuses only on Tobin's $Q$ dimension of corporate financial performance and does not focus on other performance dimensions such as market share or profitability. Future study should consider similar dimensions (e.g. ROE, ROA, market value added, economic value added) as a proxy of corporate finance performance. Second, this study had a relatively small number of samples, only 22 firms were used. Future studies are expected to increase the number of samples so that it will provide a greater likelihood to obtain the actual conditions. Third, this study focused only on the GRI dimension of corporate social responsibility.The future studies are expected to be able to add or use other variables to find an estimate of the standard model of corporate social responsibility. Fourth, this study focuses on the stock return as a dependent variable and does not consider the risk. Future studies should focus on performance measures that are related to financial risk andtheir impact on the market rate of return.

\section{References}

Anwaar, M. (2016). Impact of firms' performance on stock returns (evidence from listed companies of FTSE-100 Index London, UK). Global Journal of Management and Business Research, 16(1), $1-10$.

Brammer, S., Brooks, C., \& Pavelin, S. (2006). Corporate Social performance and stock returns: UK evidence from disaggregate measures. Financial Management, 35(3), 97-116.

Cochran, P. L. \& Wood, R. A. (1984). Corporate social responsibility and financial performance. Academy of Management Journal, 27(1), 42-56.

Cormier, D. \& Magnan, M. (2007). The revisited contribution of environmental reporting to investors' valuation of a firm's earnings: An international perspective. Ecological Economics, 62, 613-626.

Demirbag, M., Tatoglu, E., Tekinus, M., \& Zaim, S. (2006). An analysis of the relationship between TQM implementation and organizational performance: Evidence from Turkish SMEs. Journal of Manufacturing Technology Management, 17 (6), 829-847.

Derwall, J., Guenster, N., Bauer, R., \& Koedijk, K. (2005). The eco-efficiency premium puzzle. $\mathrm{Fi}$ nancial Analysts Journal, 61(2), 51-63.

Friedman, M. (1970). The social responsibility of business is to increase its profits. The New York Times Magazine. 
Garcia-Castro, R., Arino, M. A., \& Canela, M. A. (2010). Does social performance really lead to financial performance? Accounting for endogeneity. Journal of Business Ethics, 92(1), 107126.

Ghozali, I. \& Ratmono, D. (2013). Analisis multivariat dan ekonometrika: teori, konsep, dan aplikasi dengan EVIEWS 8. Semarang: Badan Penerbit Universitas Diponegoro.

Guenster, N., Bauer, R., Derwall, J., \& Koedijk, K. (2011). The economic value of corporate ecoefficiency. European Financial Management, 17(4), 679-704.

Hussainey, K. \& Salama, A. (2010). The importance of corporate environmental reputation to investors. Journal of Applied Accounting Research, 11(3), 229-241.

Konar, S., \& Cohen, M. (2001). Does the market value environmental performance. The Review of Economics and Statistics, 83(2), 281-289.

Lagas, F. (2013). The effect of corporate social performance on shareholder wealth in mergers \& acquisitions. Tilburg University, School of Economics and Management.

Leite, R. C., Padgett, R. C., \& Galán, J. I. (2014). Stakeholder management and nonparticipation in controversial business. Business \& Society, 53(1), 45-70.

Margolis, J. D. \& Walsh, J. P. (2003). Misery loves companies: Rethinking social initiatives by business. Administrative Science Quarterly, 48(2), 268-305.

Moneva, J. M. \& Cuellar, B. (2009). The value relevance of financial and non-financial environmental reporting. Environmental and Resource Economics, 44(3), 441-456.

Muhammad, N.\& Scrimgeour, F. (2014). Stock returns and fundamentals in the australian market. Asian Journal of Finance \& Accounting, 6(1), 271-290.

Orlitzky, M., Schmidt, F. L., \& Rynes, S. L. (2003). Corporate social and financial performance: A meta-analysis. Organization Studies, 24, 403441.
Orlitzky, M., Schmidt, F. L., \& Rynes, S. L. (2003). Corporate social and financial performance: Ameta-analysis. Organization Studies, 24(3), 403-441.

Palmer, K., Oates, W. E., \& Portney, P. R. (1995). Tightening environmental standards: The benefit cost or the no-cost paradigm? Journal of Economic Perspectives, 9(4), 119-132.

Pan, X., Sha, J., Zhang, H., \& Ke, W. (2014). Relationship between Corporate Social responsibility and financial performance in the mineral industry: Evidence from Chinese mineral firms. Sustainability, 6, 4077-4101.

Saleh, M. (2015). Relationship between Firm's Financial Performance and Stock. Journal of Energy Technologies and Policy, 5(10).

Smirlock, M., Gilligan, T., \& Marshall, W. (1984). Tobin's $q$ and the structure-performance relationship. American Economic Review, 74(5), 10511060

Stekelenburg, A. V., Georgakopoulos, G., Sotiropoulou, V., Vasileiou, K. Z., \& Vlachos, I. (2015). The relation between sustainability performance and stock market returns: an empirical analysis of the Dow Jones sustainability Index Europe. International Journal of Economics and Finance, 7(7), 74-88.

Vintila, G. \& Nenu, E. A. (2015). An Analysis of determinants of corporate financial performance: Evidence from the bucharest stock exchange listed companies. International Journal of Economics and Financial Issues, 5(3), 732-739.

Waddhock, S.\& Graves, S. B. (1997). The corporate social performance-financial performance link. Strategic Management Journal, 18(4), 303-319.

Walley, N.\& Whitehead, B. (1994). It's not easy being green. Harvard Business Review, 72, 46-52.

Weir, C. H. (2010). How does the stock market react to corporate environmental news? Undergraduate Economic Review, 6(1), 1-31.

Wood, D. J. (1991). Corporate social performance revisited. Academy of Management Review, 16, 691-718. 